\title{
The study of the carbohydrate composition of hawthorn fruits
}

Carbohydrates, in particular monosaccharides, are necessary for the normal functioning of the human body. Therefore, the search for plant sources of available carbohydrates, such as glucose, fructose, arabinose, is relevant today.

Aim. To determine the qualitative composition and the quantitative content of monosaccharides of hawthorn fruits.

Materials and methods. Extraction of polysaccharides from the raw material was carried out with purified water in the ratio of the raw material - extractant of 1:10 and further treatment of the filtrate with $96 \%$ ethyl alcohol. The preliminary identification of sugars was performed by paper chromatography (PC) after acid hydrolysis. The qualitative composition and the quantitative content of sugars were determined by the gas chromatography-mass spectrometry method on an Agilent 6890N/5973 inert device (Agilent Technologies, USA). The total sugars were isolated by acid hydrolysis using $2 \mathrm{M}$ trifluoroacetic acid. For extraction of free sugars the mixture of methyl alcohol solution and the internal standard (the solution of sorbitol) was added to the powdered raw material.

Results and discussion. As a result of chromatography (PC) with the reliable samples glucose and fructose were identified in the raw material. By the chromatography-mass spectrometry study the presence of 5 free sugars was detected, among them glucose $(2.02 \mathrm{mg} / \mathrm{g})$, fructose $(2.21 \mathrm{mg} / \mathrm{g})$ and sucrose $(0.23 \mathrm{mg} / \mathrm{g})$ were determined. After acidic hydrolysis arabinose $(1.82 \mathrm{mg} / \mathrm{g})$, xylose $(3.88 \mathrm{mg} / \mathrm{g})$, mannose $(4.25 \mathrm{mg} / \mathrm{g})$, glucose $(5.57 \mathrm{mg} / \mathrm{g})$ and galactose $(1.31 \mathrm{mg} / \mathrm{g})$ were identified.

Conclusions. The composition of sugars in hawthorn fruit has been found. The highest content has been determined for fructose, glucose and mannose.

Key words: hawthorn; fruits; sugars

\section{Н. В. Сидора, А. М. Ковальова, В. К. Яковенко}

\section{Дослідження вуглеводного складу плодів глоду}

Вуглеводи, зокрема моноцукри, необхідні для нормального функціонування організму людини. Тому актуальним є пошук рослинних джерел доступних вуглеводів таких як глюкоза, фруктоза, арабіноза.

Метою даної роботи є встановлення якісного складу та кількісного вмісту моноцукрів плодів глоду.

Матеріали та методи. Екстракцію полісахаридів з сировини проводили водою очищеною у співвідношенні сировина-екстрагент 1 : 10 та наступною обробкою фрільтрату спиртом етиловим $96 \%$. Попередню ідентифікацію моноцукрового складу проводили методом паперової хроматографії (ПХ) після кислотного гідролізу. Якісний склад та кількісний вміст моноцукрів визначали методом газорідинної хромато-мас-спектрометрії на приладі Agilent 6890N/5973 inert, (Agilent Technologies, USA). Загальні моноцукри виділяли кислотним гідролізом з використанням 2 М кислоти трифторооцтової. Для екстракції вільних моноцукрів до перетертої у порошок сировини додавали суміш розчину метилового спирту з внутрішнім стандартом (розчин сорбітолу).

Результати та їх обговорення. В результаті хроматографування (ПХ) з вірогідними зразками в сировині було ідентифіковано глюкозу та фруктозу. При проведенні хромато-мас-спектрометричного дослідження встановлено присутність 5 вільних цукрів, з яких ідентифіковано глюкозу (2,02 мг/г), фруктозу (2,21 мг/г) та цукрозу $(0,23 \mathrm{mг/r).} \mathrm{Після} \mathrm{кислотного} \mathrm{гідролізу} \mathrm{ідентиффіковано} \mathrm{арабінозу} \mathrm{(1,82} \mathrm{мг/г),} \mathrm{ксилолу} \mathrm{(3,88} \mathrm{мг/г),} \mathrm{манозу}(4,25$ мг/г), глюкозу (5,57 мг/г) та галактозу (1,31 мг/г).

Висновки. Встановлено моноцукровий склад плодів глоду. Найбільший вміст визначено для фруктози, глюкози та манози.

Ключові слова: глід; плоди; цукри

\section{Н. В. Сидора, А. М. Ковалева, В. К. Яковенко}

\section{Изучение углеводного состава плодов боярышника}

Углеводы, в частности моносахара, необходимы для нормального функционирования человеческого организма. Поэтому актуальным является поиск растительных источников доступных углеводов, таких как глюкоза, фруктоза, арабиноза.

Целью данной работы является установление качественного состава и количественного содержания моносахаров плодов боярышника.

Материалы и методы. Экстракцию полисахаридов из сырья проводили водой очищенной в соотношении сырье-экстрагент 1 : 10 и последующей обработкой фильтрата спиртом этиловым $96 \%$. Предварительную идентификацию моносахаридного состава проводили методом бумажной хроматографии (БХ) после кислотного гидролиза. Качественный состав и количественное содержание моносахаров определяли методом газожидкостной хромато-масс-спектрометрии на приборе Agilent 6890N/5973 inert, (Agilent Technologies, USA). Oбщие моносахара выделяли кислотным гидролизом с использованием 2 М кислоты трифторуксусной. Для экстракции свободных моносахаров к перетертому в порошок сырью добавляли смесь раствора метилового спирта с внутренним стандартом (раствор сорбитола). 
Результаты и их обсуждение. В результате хроматографирования (БХ) с достоверными образцами в сырье були идентифицированы глюкоза и фррукоза. При проведении хромато-масс-спектрометрического исследования установлено присутствие 5 свободных сахаров, из которых идентифицировано глюкозу $(2,02$ мг/г), фруктозу $(2,21 \mathrm{mг} / г)$ и сахарозу $(0,23 \mathrm{mr} / г)$. После кислотного гидролиза идентифицировано арабинозу $(1,82 \mathrm{mr} / г)$, ксилолу (3,88 мг/г), маннозу (4,25 мг/г), глюкозу (5,57 мг/г) и галактозу (1,31 мг/г).

Выводы. Установлен моносахаридный состав плодов боярышника. Наибольшее содержание определено для фрруктозы, глюкозы и маннозы.

Ключевые слова: боярышник; плоды; сахара

Monosaccharides are an important part of the daily human diet. These compounds are necessary for the normal functioning of the body [1]. Moreover, glucose is the source of energy for organs and tissues, and it is actively used by the muscles; fructose is involved in metabolic processes; ribose is a component of deoxyribonucleinic acid [2]. The search for plant sources of available carbohydrates is relevant today. As we reported earlier, in fruits of North American hawthorn species a significant content of water-soluble polysaccharides was found. Therefore, in our opinion, the profound study of the carbohydrate composition of this raw material is of scientific interest.

The aim of the work is to determine the qualitative composition and the quantitative content of monosaccharides of hawthorn fruits.

\section{Materials and methods}

The objects of the study were the hawthorn fruit of the North American group with a sweet, juicy pulp $[3,4]$.

The raw material was collected in the phase of full ripeness in August 2017 (Botanical Garden of the National University of V. N. Karazin).

Preparation and the study of polysaccharides. Polysaccharides were isolated from the raw material by heating with purified water in the ratio of $1: 10$ and with the subsequent addition of $96 \%$ ethyl alcohol. The precipitate formed was separated by centrifugation for $2 \mathrm{~min}$ and dried in a dryer at the temperature of $35^{\circ} \mathrm{C}[5,6]$.

The resulting polysaccharides were hydrolyzed with $10 \%$ sulfate acid while heating. The hydrolyzate was chromatographed in the butanol - acetic acid - water solvent system $(4: 1: 2)$ with reliable samples of sugars (D-glucose, L-arabinose, D-fructose, D-xylose) [7]. The chromatograms obtained were treated with aniline phthalate and kept in a drying cabinet for $1 \mathrm{~min}$. After chromatography and processing the formation of brown spots was observed. By color and the value of Rf glucose and fructose were identified in the raw material and compared to the reliable samples [8].

The study of monosaccharides by gas-liquid chromatography-mass spectrometry. The sample preparation of the raw material was based on extraction of the total and free sugars in different conditions.

Isolation of the total sugars. The raw material was powdered, the accurate weight $(500 \mathrm{mg})$ was placed in a round bottom flask, $5 \mathrm{ml}$ of $2 \mathrm{M}$ trifluoroacetic acid was added, and polysaccharides were hydrolyzed for $6 \mathrm{~h}$. Then $2 \mathrm{ml}$ of the hydrolyzate were collected, evaporated, washed with water to remove trifluoroacetic acid. Resuspending was carried out by adding $2 \mathrm{ml}$ of the internal standard (the sorbitol solution) [9].
Isolation of free monosaccharides. Free monosaccharides were extracted from the powdered raw material. For this purpose, the mixture of methanol solution with the internal standard (the sorbitol solution) was added to $500 \mathrm{mg}$ of the raw material (accurate weight). Free polysaccharides were isolated at $80^{\circ} \mathrm{C}$ for $4 \mathrm{~h}$ using an ultrasound bath.

The qualitative composition and the quantitative content of monosaccharides were determined by the gas chromatography-mass spectrometry method. This method is based on extraction of free sugars and obtaining of acetates of their aldonitrile derivatives.

Experimental conditions: for the chromatographic separation the Agilent 6890N/5973 inert gas chromatography-mass spectrometry system (Agilent Technologies, USA) was used: a HP- 5 capillary column $(30 \mathrm{~m} \times 0.25 \mathrm{~mm} \times$ $0.25 \mu \mathrm{m}$ Agilent Technologies, USA); evaporation temperature $-250^{\circ} \mathrm{C}$, the interface temperature $-280^{\circ} \mathrm{C}$; separation in the programmed temperature, the initial temperature of $160^{\circ} \mathrm{C}$ was maintained for $8 \mathrm{~min}$, then raised to $240{ }^{\circ} \mathrm{C}$ (with a gradient of $5^{\circ} \mathrm{C} / \mathrm{min}$ ) and maintained at the final temperature of $6 \mathrm{~min} ; 1 \mu \mathrm{l}$ of the sample were injected in the flow separation mode of $1: 50$. Detection was performed in the SCAN mode (the range of 38-400 m/z). The speed of the gas-carrier was $1.2 \mathrm{ml} / \mathrm{min}[9,10]$.

\section{Results and discussion}

Identification of monosaccharides was carried out by comparing the retention time of standard sugars and using the database of the NIST 02 mass spectrometry library. The quantitative analysis was performed by adding the internal standard solution (the sorbitol solution) to the test samples [10].

The mass of monosaccharides (mg) per $1 \mathrm{~kg}$ of the raw material was calculated using the formula:

$$
X=\frac{S_{x} \cdot M_{\text {in.st. }} \cdot 1000}{S_{\text {in.st. }} \cdot m}
$$

where: $S_{x}$ - is the peak area of a monosaccharide; $M_{\text {in.st. }}{ }^{-}$ is the mass of the internal standard for the sample; $S_{\text {in.st. }}-$ is the peak area of the internal standard; $m$ - is the sample weight.

The chromatogram of free monosaccharides and monosaccharides after hydrolysis are shown in Fig. 1, 2.

Monosaccharides identified in the raw material are shown in Table.

As shown in Table, in hawthorn fruit 5 free sugars were detected, of them 3 were identified (glucose, fructose, sucrose); after acid hydrolysis the presence of 6 compounds was detected, among them 5 were identified 


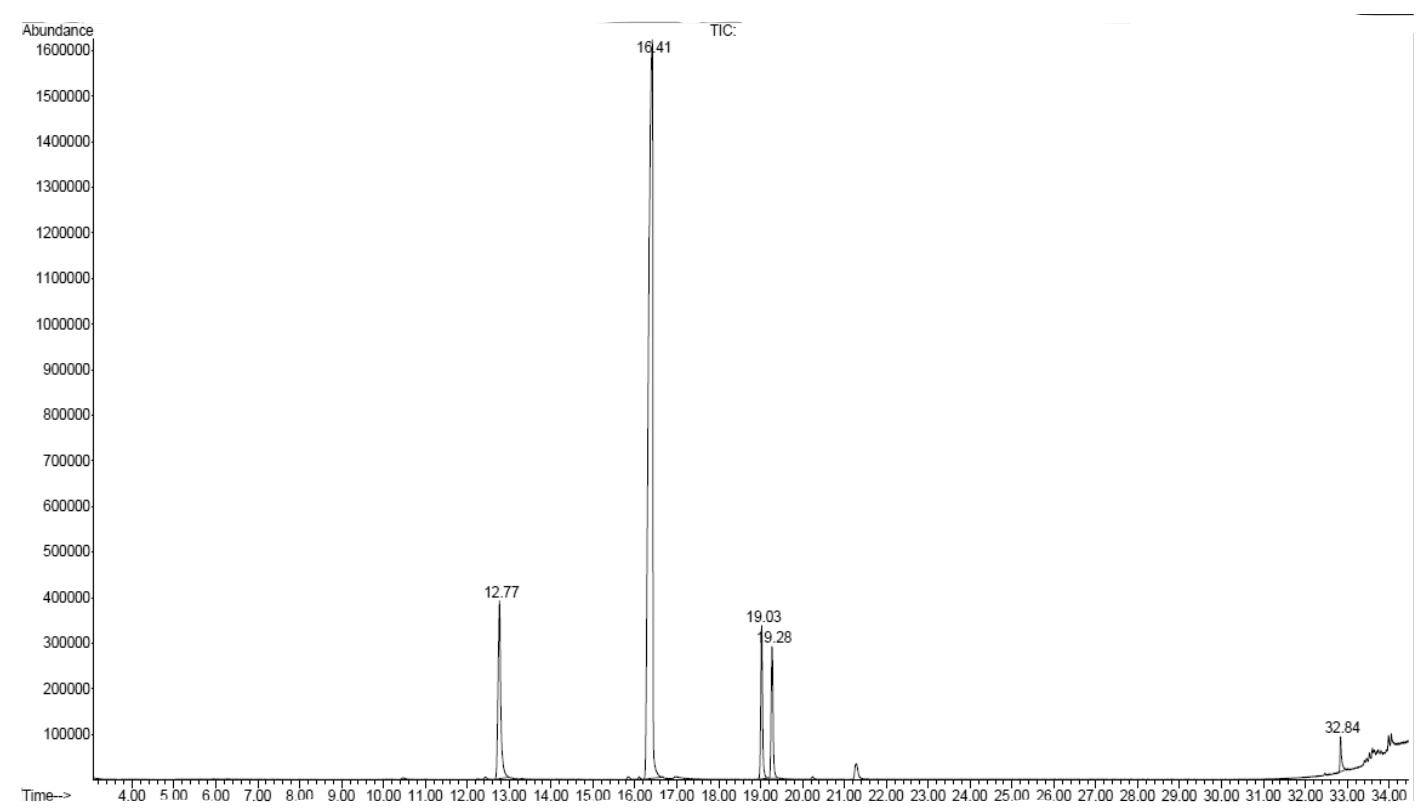

Fig. 1. The chromatogram of free monosaccharides and sucrose of hawthorn fruit

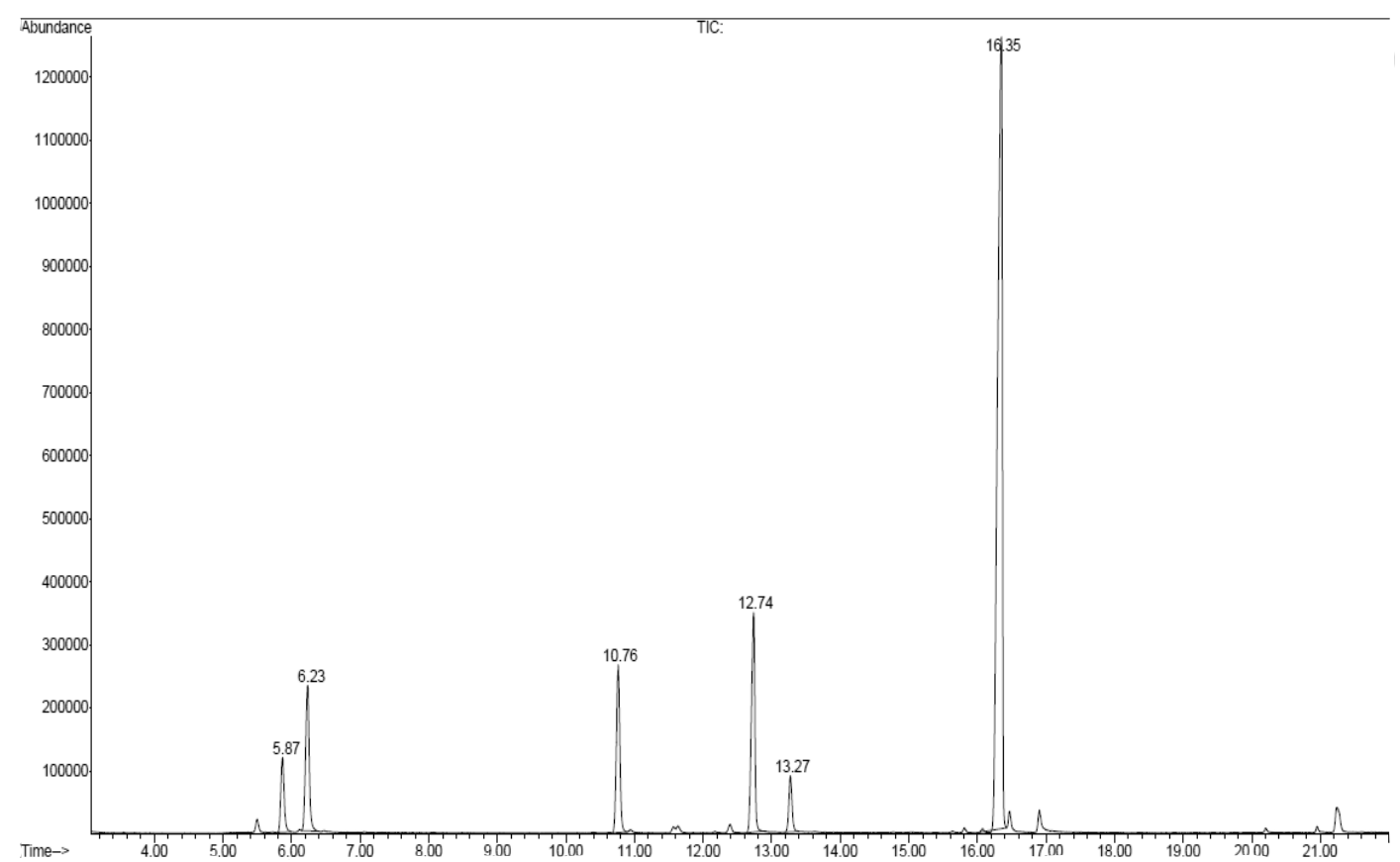

Fig. 2. The chromatogram of monosaccharides of hawthorn fruit after acid hydrolysis

Monosaccharides identified in the raw material

\begin{tabular}{|l|c|c|}
\hline \multicolumn{2}{|c|}{ Compound } & Retention time, min \\
\hline \multicolumn{2}{|c|}{ Free sugars } \\
\hline Glucose & 12.77 & 2.02 \\
\hline Fructose & 19.02 & 2.21 \\
\hline Sucrose & 32.84 & 0.23 \\
\hline \multicolumn{3}{|c|}{ Sugars after acid hydrolysis } \\
\hline Arabinose & 5.86 & 1.82 \\
\hline Xylose & 6.23 & 3.88 \\
\hline Mannose & 10.76 & 4.25 \\
\hline Glucose & 12.73 & 5.57 \\
\hline Galactose & 13.27 & 1.31 \\
\hline
\end{tabular}


(arabinose, xylose, mannose, glucose, galactose). By the quantitative content in the free form fructose dominated $(2.21 \mathrm{mg} / \mathrm{g})$. Among sugars after acid hydrolysis the highest content was determined for glucose $(5.57 \mathrm{mg} / \mathrm{g})$ and mannose $(4.25 \mathrm{mg} / \mathrm{g})$.

CONCLUSIONS

1. In hawthorn fruits the composition of free sugars and sugars after acid hydrolysis has been determined.
2. Dominant sugars are fructose, glucose and mannose.

3 . The results obtained indicate the use perspectiveness of hawthorn fruit in medical practice as a source of monosaccharides and water-soluble polysaccharides and create the preconditions for further in-depth study of this raw material.

Conflict of Interests: authors have no conflict of interests to declare.

\section{REFFERENCES}

1. Newman, D. J. Natural products as sources of new drugs / D. J. Newman, G. M. Cragg // J. Nat. Prod. - 2016. - Vol. 79. - P. 629-661. https://doi.org/10.1021/acs.jnatprod.5b01055

2. Nicolae, S. Chemical and biochemical components in fruit and their role in the human health / S. Nicolae, A. Paul-Badescu, C. Nicola, C. Parvan // Fruit Growing Res. - 2008. - Vol. 24. - P. 138-143.

3. Phipps, J. B. Origin and evolution of subfam. Maloideae (Rosaceae) / J. B. Phipps, K. R. Robertson, J. R. Rohrer, P. G. Smith // Systematic Botany. - 1991. - Vol. 16, Issue 4. - P. 302-332. https://doi.org/10.2307/2419283

4. Kirtikar, K. R. Rosaceae / K. R. Kirtikar, B. D. Basu, K. S. Mhaskar // Ind. Med. Plants. - 1984. - P. 951-965.

5. Сидора, Н. В. Технологічні аспекти комплексної переробки плодів глоду / Н. В. Сидора, А. М. Ковальова, В. К. Яковенко // Вісник фармації. - 2018. - № 2 (94). - C. 1-5. https://doi.org/10.24959/nphj.18.2208

6. Державна фармакопея України / Державне підприємство «Український науковий фармакопейний центр якості лікарських засобів». - 2-е вид. - Х.: Український науковий фармакопейний центр якості лікарських засобів, 2014. - 732 с.

7. Самойлова, В. А. Вивчення полісахаридів листя аронії: тези доп. / В. А. Самойлова, В. М. Ковальов // Функціональні харчові продукти - дієтичні добавки як дієвий засіб різнопланової профілактики захворювань. - Х., 2013. - С. 200.

8. Boggs, L. Separation and identification of sugars using paper chromatography / L. Boggs, L. S. Cuendet, R. Koch // Nature J. - 1950. Vol. 166. - P. 520-521. https://doi.org/10.1038/166520b0

9. Matias, J. Analysis of sugars by liquid chromatography - mass spectrometry in Jerusalem artichoke tubers for bioethanol production optimization / J. Matias, L. Royano, R. Barrena // Biomass and Bioenergy. - Vol. 35 (5). - 2011. - P. 2006-2012. https://doi.org/10.11603/ mcch.2410-681x.2018.v0.i1.8885

10. Дослідження вуглеводів кореневищ і коренів та трави родовика лікарського (Sanguisorba officinalis L.) / С. М. Марчишин, В. В. Кудря, I. С. Дахим, О. В. Зарічанська // Мед. та клін. хімія. - 2018. - Т. 20, № 1. - С. 93-99. https://doi.org/10.1016/j.biombioe.2011.01.056

\section{REFFERENCES}

1. Newman, D. J., Cragg, G. M. (2016). Natural products as sources of new drugs. J. Nat. Prod., 79, 629-661. https://doi.org/10.1021/acs. jnatprod.5b01055

2. Nicolae, S., Paul-Badescu, A., Nicola, C., Parvan, C. (2008). Chemical and biochemical components in fruit and their role in the human health. Fruit growing research, 24, 138-143.

3. Phipps, J. B., Robertson, K. R., Rohrer, J. R., Smith, P. G. (1991). Origin and evolution of Subfam. Maloideae (Rosaceae). Systematic Botany, 16 (2), 302-332. https://doi.org/10.2307/2419283

4. Kirtikar, K. R., Basu, K. S., Mhaskar, K. S. (1984). Rosaceae. Indian Medicinal Plants, 951-965.

5. Sidora, N. V., Kovaleva, A. M., Yakovenko, V. K. (2018). Visnik Farmacii, 2 (94), 1-5. https://doi.org/10.24959/nphj.18.2208

6. Derzhavne pidpyiemstvo "Ukrainsky nakovyi ekspertnyi farmakopeini tsentr yakosti likarskykh zasobiv. (2015). Derzhavna Farmakopeia Ukrainy. (2-nded.). Kharkiv, 723.

7. Samoilova, V. A.,Kovalev, V. M. (2013). Funktsionalni kharchovi produkty - diietychni dobavky - yak diievyi zasib riznoplanovoi profilaktyky zakhvoriuvan. Kharkiv, 200.

8. Boggs, L., Cuendet, L. S., Ehrenthal, I., Koch, R., \& Smith, F. (1950). Separation and Identification of Sugars using Paper Chromatography. Nature, 166(4221),520-521. https://doi.org/10.1038/166520b0

9. Marchishin, S. M., Kudria, V. V., Dachim, O. V., Zarichanska, O. V. (2018). Medychna ta klinichna khimiia, 20,(1), 93-99. https://doi. org/10.1016/j.biombioe.2011.01.056

10. Matías, J., González, J., Royano, L., \&Barrena, R. A. (2011). Analysis of sugars by liquid chromatography-mass spectrometry in Jerusalem artichoke tubers for bioethanol production optimization. Biomass and Bioenergy, 35(5), 2006-2012. https://doi.org/10.11603/ mcch.2410-681x.2018.v0.i1.8885 
Information about authors:

Sydora N. V., Candidate of Pharmacy (Ph D), associate professor of the Pharmacognosy Department, National University of Pharmacy

E-mail: sydora2005@gmail.com. ORCID: http://orcid.org/0000-0002-3333-2250

Kovalyova A. M., Doctor of Pharmacy (Dr. habil), professor of the Pharmacognosy Department, National University of Pharmacy.

E-mail: allapharm@yahoo.com. ORCID: http://orcid.org/0000-0002-1758-1222

Iakovenko V. K., Doctor of Pharmacy, (Dr. habil), professor of the Industrial Pharmacy and Economy Department. E-mail: v.iakovenko@gmail.com.

ORCID: http://orcid.org/0000-0002-9348-7764

Відомості про авторів:

Сидора Н. В., канд. фарм. наук, доцент кафедри фармакогнозії, Національний фармацевтичний університет. E-mail: sydora2005@gmail.com. ORCID: http://orcid.org/0000-0002-3333-2250

Ковальова A. М., д-р фарм. наук, професор кафедри фармакогнозії, Національний фармацевтичний університет. E-mail: allapharm@уahoo.com. ORCID: http://orcid.org/0000-0002-1758-1222

Яковенко В. К., д-р фарм. наук, професор кафедри промислової фармації та економіки. E-mail: v.iakovenko@gmail.com.

ORCID: http://orcid.org/0000-0002-9348-7764

Сведения об авторах:

Сидора Н. В., канд. фарм. наук, доцент кафедры фармакогнозии, Национальный фармацевтический университет. E-mail: sydora2005@gmail.com. ORCID: http://orcid.org/0000-0002-3333-2250

Ковалева А. М., д-р фарм. наук, профессор кафедры фармакогнозии, Национальный фармацевтический университет. E-mail: allapharm@уаhоо.сот. ORCID: http://orcid.org/0000-0002-1758-1222

Яковенко В. К., д-р фарм. наук, профессор кафедры промышленной фармации и экономики. E-mail: v.iakovenko@gmail.com.

ORCID: http://orcid.org/0000-0002-9348-7764 